OPEN ACCESS

Edited by:

Krithi K. Karanth

Wildlife Conservation Society, India

Reviewed by:

Zuzana Burivalova,

Princeton University, United States Nathalie Van Vliet,

Center for International Forestry Research, Indonesia

*Correspondence: David S. Wilkie

dwikie@wcs.org

Specialty section:

This article was submitted to Conservation,

a section of the journal

Frontiers in Ecology and Evolution

Received: 19 October 2018 Accepted: 09 September 2019 Published: 24 September 2019

Citation:

Wilkie DS, Wieland M and Poulsen JR (2019) Unsustainable vs. Sustainable Hunting for Food in Gabon: Modeling

Short- and Long-Term Gains and Losses. Front. Ecol. Evol. 7:357 doi: 10.3389/fevo.2019.00357

\section{Unsustainable vs. Sustainable Hunting for Food in Gabon: Modeling Short- and Long-Term Gains and Losses}

\author{
David S. Wilkie ${ }^{1 *}$, Michelle Wieland ${ }^{2}$ and John R. Poulsen ${ }^{3}$ \\ ${ }^{1}$ Global Conservation Program, Wildlife Conservation Society, Bronx, NY, United States, ${ }^{2}$ Africa Program, Wildlife \\ Conservation Society, Bronx, NY, United States, ${ }^{3}$ Nicholas School of the Environment, Duke University, Durham, NC, \\ United States
}

Today, rural people continue to consume wild animals (aquatic and terrestrial) because they are often cheaper and more available than farmed livestock and fish. In many places where the meat from wild animals is an important source of food and income for poor rural families, the capture, consumption or trade of wild animals is illegal and remains within the informal sector and outside of national accounting and regulatory systems. Few studies exist to help policy makers and wildlife managers develop and implement systems designed to halt unsustainable hunting, prevent species loss, and maintain, over the long term, flows of wildlife available to people as a source of food and income. This paper uses empirical data from a tropical forest area in Gabon within a heuristic simulation model to explore how hunter capture rates would need to change over time to halt unsustainable hunting and to maximize the nutritional and economic value of wildlife as a source of food and income over the long term. Results show that sustainable hunting of wildlife populations that are at or near $50 \%$ of carrying capacity $(0.5 \mathrm{~K})$ generates more biomass available for consumption and income generation over 25 years than either hunting to maintain current population densities or continuing to hunt unsustainably. Unsustainable hunting generates more biomass than sustainable hunting but only for the first 1 to 3 years after which offtake dwindles rapidly. Achieving sustainable hunting will require that hunters reduce their offtake for 3-13 years until depleted populations recover, which may be unlikely unless they have access to alternative sources of food and income.

Keywords: bushmeat, hunting, unsustainable, protein deficit, simulation

\section{INTRODUCTION}

Across the planet many forests, grasslands, rivers, lakes, and coastal waters are empty or being emptied of their wildlife to meet growing human demand for animal-source foods. If demand exceeds the capacity of a wildlife population to replace harvested individuals the population will decline, potentially to local extinction.

The human population continues to grow by over 80 million people annually and is expected to reach 8.6 billion by 2030 (Desa, 2015) - nearly nine times the human population in 1,800. Half of the future increase in human population will be in Africa, and by 2030 one in every four people will be African (Desa, 2015). We are increasingly becoming an urban species, and global economic 
development and poverty alleviation is making most of us wealthier, changing what we want and can afford to eat (Bodirsky et al., 2015). This combination of growth, urbanization, and wealth is driving up demand for animalsource foods (Alexandratos and Bruinsma, 2012). In many places, production of animal-source foods is not keeping pace with growing demand, and hunting and fishing of wild animals often increases to unsustainable levels to fill the gap (Wilkie et al., 2011; Ripple et al., 2016).

If this situation continues unchanged, we risk the wide-spread loss of aquatic and terrestrial biodiversity as hungry people eat species after species to extinction (Ripple et al., 2016). Millions of people, particularly poor people, will face a looming protein deficit that will make child malnutrition and "failure to thrive" an appalling norm (Golden et al., 2011). Loss of wildlife populations used as food will change plant and animal species composition and distribution within ecosystems (Poulsen et al., 2013; Trolliet et al., 2019). As a consequence, food webs will be disrupted and destabilized, decreasing ecosystem resilience to climate shocks and risking a cascade of species extinctions.

Estimates of the current volume and value of wild caught terrestrial and aquatic animals are encouraging many governments and development assistance organizations to promote policies that would legalize the trade in wildlife as food and bring this largely informal, weakly regulated economy into a more regulated marketplace. However, guiding policy reform solely on the current dietary and financial value of wildlife used as food fails to take into account that most wildlife populations captured for food are being over-exploited, and thus current capture rates are too high and cannot be sustained over the long-term.

Few studies exist to help policy makers and wildlife managers develop and implement systems designed to halt unsustainable hunting, prevent species loss, and maintain, over the long term, flows of wildlife as a source of food and income (Robinson and Bennett, 2000b; Bennett et al., 2007). Studies that explore the impact that different management decisions would likely have on wildlife population status and annual productivity are particularly lacking. Exploring different scenarios would help determine the approaches for optimizing both species conservation and maintenance of wildlife as a provisioning ecosystem service delivering food and income to families.

This paper uses empirical estimates of the abundance of hunted species in the forests of Gabon to simulate, over 25 years, the impact of three different hunting management scenarios, on wildlife populations, annual production of wildlife, and the benefits wildlife confer to people as a source of food and income. The three scenarios are: (1) reduction of hunting to sustainable levels at current wildlife population densities; (2) managing annual harvest levels (offtake) to move the hunted wildlife population levels toward $50 \%$ of carrying capacity $(0.5 \mathrm{~K})$ where annual production is greatest, enabling maximum sustainable offtake; and, (3) business-as-usual (i.e., continuation of unsustainable hunting).

We acknowledge that the model presented in this paper is, like all models, a simplification of reality. But as the statistician George Box so sagely noted "All models are wrong, but some are useful" (Box, 1979). Our model is offered as a heuristic device designed to explore the outcomes of different approaches to managing hunting of wildlife for food and income. Whether managers and policy makers: (a) should attempt to halt unsustainable hunting through spatial closures, individual or community quotas, exclusion of non-rights holders, or taxation and (b) how they should assess what is or is not sustainable offtake is beyond the scope of this paper.

\section{MATERIALS AND METHODS}

To explore what happens to the supply of wild meat as hunting transitions from being unsustainable to sustainable, we will use an example based on data reported from recent research in $5,807 \mathrm{~km}^{2}$ of tropical moist forest around the town of Makokou, Gabon (Koerner et al., 2017). The authors conducted surveys of terrestrial and arboreal wildlife within three zones of increasing distance from villages $\left(0-6 \mathrm{~km}\right.$ to $1,871 \mathrm{~km}^{2}, 6-15 \mathrm{~km}$ to 2,126 $\mathrm{km}^{2}$, and $>15 \mathrm{~km}$ to $1,830 \mathrm{~km}^{2}$ ).

For this hunting simulation we focus on three monkey species (Cercopithecus mona pogonias-crested mona monkey, C. n. nictitans-great white-nosed monkey, and Lophocebus albigena-gray-cheeked mangabey), and small (Cephalophus monticola-blue duiker) and medium-size duikers ( $C$. callipygus-peters duiker, C. leucogaster- white-bellied duiker, and C. dorsalis castaneus-bay duiker). These were chosen because Koerner et al. (2017) report estimates of their densities (Table 1) and they are the most commonly hunted, traded and consumed species when wildlife populations are not depleted from overhunting (Abernethy et al., 2013). For each species or species group (e.g., medium-sized duikers), we used density data within each zone to calculate total abundance. To calculate sustainable yield, $H$-the number of animals that can be taken from a population of any size over an indefinite period without depleting the stock, we used the standard Gordon-Schaefer equation under the assumption of logistic population growth.

$$
r \mathrm{~S}_{\mathrm{t}}\left(1-\mathrm{S}_{\mathrm{t}} / \mathrm{K}\right)=\mathrm{H}_{\mathrm{t}}
$$

The intrinsic rate of population growth $(r)$ for each species was drawn from the literature (Fa et al., 1995) or computed using Cole's equation (Cole, 1954). Several studies suggest that most hunting in central Africa occurs within approximately $15 \mathrm{~km}$ of settlements (Abernethy et al., 2013; Coad et al., 2013; Beirne et al., 2019). Given this we assumed that the area further than $15 \mathrm{~km}$ from villages can serve as a largely unhunted reference point where populations are close to or at carrying capacity $(K) . S_{t}$ is the stock (abundance) and $H_{t}$ the sustainable yield of a hunted species at time $t$. Because the annual population growth rate $(d S / d t)$ when plotted against population size $(S)$ is shaped like an inverted U (Figure 1), sustainable yield will be the same when a population is near zero (say $0.01 \mathrm{~K}$ ) or near carrying capacity (say $0.99 \mathrm{~K}$ ), and will be maximized around $0.5 \mathrm{~K}$ (i.e., maximum sustainable yield-MSY) where a population is growing at its fastest rate. We understand the risks of harvesting a population at MSY (Reynolds et al., 2001) 
TABLE 1 | Intrinsic rate of increase, average adult body weight, and density of hunted primates and ungulates within the Makokou study area, Gabon.

\begin{tabular}{|c|c|c|c|c|c|}
\hline \multirow[b]{2}{*}{ Species } & \multirow[b]{2}{*}{$\mathbf{r}$} & \multirow[b]{2}{*}{ Avg adult weight (kg) } & \multirow[t]{2}{*}{ Near $<6 \mathrm{~km}$} & Intermediate 6-15 km & \multirow[t]{2}{*}{ Far $>15$ km } \\
\hline & & & & Density (\#/km2) & \\
\hline Great white-nosed monkey (C. nictitans) & 1.12 & 3.8 & 6.01 & 11.19 & 17.42 \\
\hline Crested mona monkey & 1.12 & 3.6 & 4.54 & 8.13 & 13.17 \\
\hline Gray-cheeked mangabey & 1.19 & 7.7 & 2.14 & 4.34 & 8.10 \\
\hline Medium- size duikers & 1.54 & 16.0 & 1.20 & 2.67 & 7.33 \\
\hline Blue duiker & 1.63 & 4.7 & 1.31 & 2.18 & 3.43 \\
\hline \multicolumn{6}{|l|}{ Data sources } \\
\hline \multicolumn{6}{|l|}{ r from Fa et al. (1995) and Cole (1954) } \\
\hline \multicolumn{6}{|l|}{ Avg adult weight from Kingdon et al. (2013) } \\
\hline Density from Koerner et al. (2017) & & & & & \\
\hline
\end{tabular}

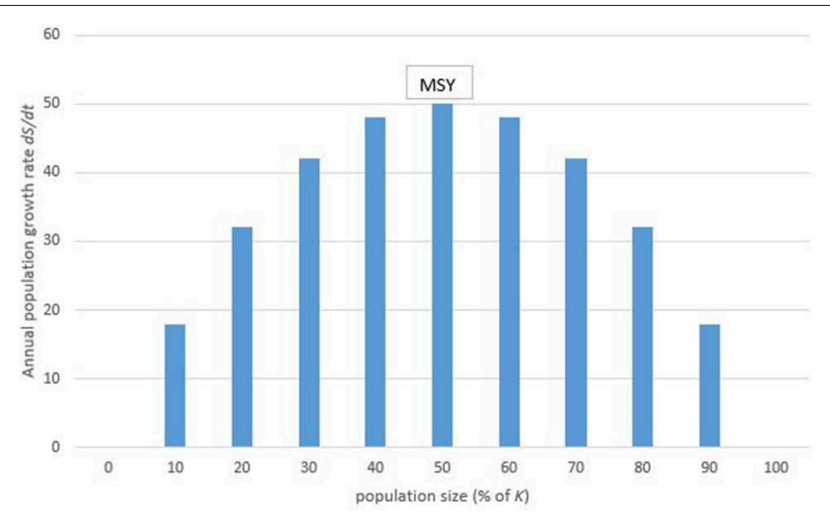

FIGURE 1 | The annual wildlife production curve, assuming logistic growth, follows an inverted $U$ shape with production maximized at $0.5 \mathrm{~K}$.

and are not advocating this as a hunting management strategy. Rather, we are simply using the concept in the model to estimate the maximum sustainable offtake that is theoretically possible. In reality, a more precautionary approach where offtake is set less than MSY would reduce the risk of over-exploitation and local extinction.

We simulated offtake over a 25-year period for three scenarios: (1) sustainable hunting at current population densities; (2) maximum sustainable yield when population levels were at $0.5 \mathrm{~K}$; and, (3) unsustainable business-as-usual hunting. Achieving MSY requires that the initial population at $t_{0}$ grow or shrink to $0.5 \mathrm{~K}$. To allow a population to grow, offtake was set at 10 , 25 , or 50 percent below sustainable yield to leave a surplus to increase $S$ in time $t+1$. If the initial population was above $0.5 \mathrm{~K}$ offtake was increased to 10,25 , or 50 percent above sustainable yield to deplete the population to $0.5 \mathrm{~K}$. By manipulating offtake to 10,25 , or 50 percent below or above sustainable yield, the model is able to influence how rapidly the population level of each hunted species reaches $0.5 \mathrm{~K}$-the higher the percentage the more quickly $0.5 \mathrm{~K}$ is obtained. For the business-as-usual scenario, we set offtake 10, 25, or 50 percent above sustainable yield. For all three scenarios, the abundance of each species within the near $(<6 \mathrm{~km})$ and intermediate $(6-15 \mathrm{~km})$ zones at $t_{0}$ was set using their empirically measured density (Koerner et al., 2017).
Abundance within the far zone $(>15 \mathrm{~km})$ at $\mathrm{t}_{0}$ was set at $90 \%$ of the empirical value (i.e., $0.9 \mathrm{~K}$ ) so that the sustainable yield calculation would be $>0$. We converted offtake of individuals to biomass using average adult body weight from the literature (Kingdon et al., 2013).

From meat consumption studies in Gabon (Starkey, 2004; Wilkie et al., 2005; Foerster et al., 2012), we know that an average individual (reported as an Adult Male Equivalent) consumes $0.25 \mathrm{~kg}$ of wild meat per day in rural villages. This is approximately $100 \%$ of daily protein requirements as specified by the World Health Organization. Daily consumption of wild meat declines to $0.12 \mathrm{~kg} / \mathrm{AME} /$ day in provincial towns (like Makokou) and $0.02 \mathrm{~kg} / \mathrm{AME} /$ day in large cities (like Libreville). Using these figures, we calculated how many consumers in villages, towns or cities could be supplied, based on current consumption patterns, with wild meat over time from unsustainable or sustainable hunting within 6 and $15 \mathrm{~km}$ of settlements, and within the total study area of $5,807 \mathrm{~km}^{2}$.

\section{RESULTS}

Assuming that wildlife populations in the largely unhunted area $>15 \mathrm{~km}$ from settlements are close to or at carrying capacity, the Koerner et al. (2017) data suggest that the near zone wildlife populations within $6 \mathrm{~km}$ from settlements are already overexploited averaging $0.3 \mathrm{~K}$. The intermediate zone populations are currently being hunted at $0.56 \mathrm{~K}$ (i.e., close to MSY). As expected based on hunters' preference for large bodied species, mid-size duikers appear to be more heavily depleted than smaller bodied species both in the near $(0.16$ vs. $0.38 \mathrm{~K})$ and intermediate $(0.36$ vs. $0.64 \mathrm{~K}$ ) zones (Table 1 ).

Within the near zone the abundance of all species populations at $t_{0}$ are below $0.5 \mathrm{~K}$. In the intermediate zone only midsize duiker abundance is below $0.5 \mathrm{~K}$ at $t_{0}$. Given this, even if hunters decided to hunt wildlife within the three zones to maintain, permanently, their current abundance (i.e., scenario 1-sustainable yield) this would not maximize offtake over a 25-year period, because wildlife densities are either above or below $0.5 \mathrm{~K}$ (Figure 2). For example, the blue duiker population is currently below $0.5 \mathrm{~K}$ at $t_{0}$ within the near zone $(0.38 \mathrm{~K})$ and above $0.5 \mathrm{~K}$ within the intermediate zone 


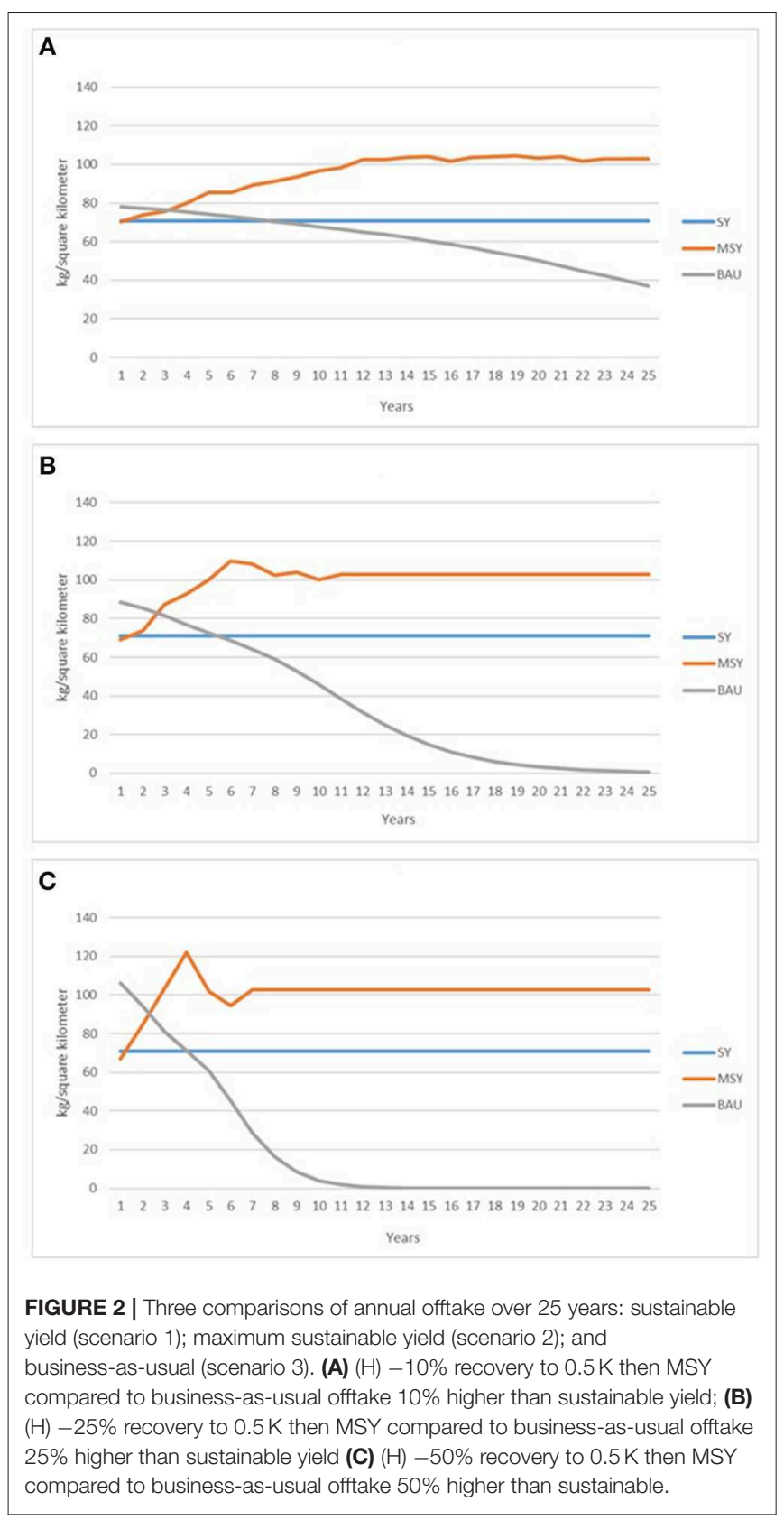

$(0.64 \mathrm{~K})$. If hunting was maintained at, or reduced to, sustainable levels such that current population levels of blue duikers did not change (scenario 1), hunting would generate $22 \%$ less biomass over a 25-year period than would a management system that increased or decreased the population to $0.5 \mathrm{~K}$ and then allowed hunting at MSY. For all modeled species combined, if hunting was to be managed at $t_{0}$ population levels sustainable offtake would generate $26-30 \%$ less biomass available for consumption or income generation than when hunted at $0.5 \mathrm{~K}$. So simply halting unsustainable hunting at $t_{0}$ population levels would not be rational if hunters maximize the rate of offtake following Charnov's (1976) marginal value theorem.
TABLE 2 | Estimated number of years that depleted wildlife populations within $6 \mathrm{~km}$ of villages in Gabon might take to recover to $0.5 \mathrm{~K}$ when offtake is reduced by 10,25 , or $50 \%$.

\begin{tabular}{lccc}
\hline Time to recovery to 0.5K & \multicolumn{3}{c}{ Years } \\
\cline { 2 - 4 } Species & $\mathbf{( H )}-\mathbf{1 0 \%}$ & $\mathbf{( H ) - 2 5 \%}$ & $\mathbf{( H ) - 5 0 \%}$ \\
\hline Great white-nosed monkey & 7 & 5 & 4 \\
Crested mona monkey & 8 & 5 & 4 \\
Gray-cheeked mangabey & 11 & 5 & 3 \\
Medium- size duikers & 13 & 7 & 5 \\
Blue duiker & 5 & 4 & 3 \\
Average & 9 & 5 & 4 \\
\hline
\end{tabular}

The estimated time to population recovery to $0.5 \mathrm{~K}$ in the near zone when offtake is reduced by 10,20 , and $50 \%$ below sustainable yield takes on average 9,4 , and 3 years, respectively (Table 2), with mid-sized duikers taking the longest time (13 years) to recover to $0.5 \mathrm{~K}$.

Reducing offtake below sustainable yield within $6 \mathrm{~km}$ from villages to allow depleted populations to recover to $0.5 \mathrm{~K}$ would require that hunters leave (i.e., not hunt) 12,679 to 15,340 animals in the forest (Table 3 ) during the recovery years (Table 2). As recovery is faster when offtake is reduced $50 \%$ below sustainable yield, the total number of animals not hunted is lower than for a 25 or $10 \%$ reduction. Reducing hunting to allow recovery of depleted wildlife populations would also reduce wild meat biomass available for consumption by 97,019 to $120,551 \mathrm{~kg}$. Similarly income to all hunters combined (assuming they sell $50 \%$ of their catch) would be reduced by $\$ 26,680$ to $\$ 33,151$ based on an average sales price of $\$ 0.55 / \mathrm{kg}$ (Gally and Jeanmart, 1996).

Though this simulation only includes a subset of all wildlife species hunted for food near Makokou, the simulated estimate of $103 \mathrm{~kg} / \mathrm{km}^{2}$ for MSY is within the lower range of estimates for maximum sustainable production in tropical forests (Robinson and Bennett, 2000a).

Hunting wildlife populations so that their abundance recovered or declined to $0.5 \mathrm{~K}$, and then hunting them at MSY always generated a higher total biomass over 25 years than sustainable yield scenario 1 , and the unsustainable businessas-usual scenario 3 (Figure 2). That said, for the first 2-3 years offtake in the business-as-usual scenario was higher than sustainable yield (scenario 1), but dropped to $50 \%$ of MSY after 19 years when offtake is $10 \%$ higher than is sustainable, 9 years when offtake is $25 \%$ higher than is sustainable, and 6 years when offtake is $50 \%$ higher than is sustainable. Unsustainable offtake falls to below $1 \%$ of MSY after 23 years when offtake is $25 \%$ higher than is sustainable and 13 years when offtake is $50 \%$ higher than is sustainable (Figure 2).

To calculate the Net Present Value of wildlife hunted for food (i.e., the current value relative to future cash returns over a given time period), we assigned a price of $\$ 1$ per $\mathrm{kg}$ and used a $20 \%$ discount rate, which is a realistic cost of capital in Gabon (i.e., the price lenders charge borrowers). NPV was higher for the business-as-usual scenario only during the first 5 years with a $10 \%$ unsustainable hunting rate. In all other 
TABLE 3 | Reduction in: (a) animals hunted; (b) biomass available for consumption or sale; and, (c) economic value to hunters when hunting of depleted wildlife within $6 \mathrm{~km}$ of villages is reduced by 10,25 , or $50 \%$ below sustainable yield $(H)$ to allow populations to recover to $0.5 \mathrm{~K}$.

\begin{tabular}{|c|c|c|c|c|c|c|c|c|c|}
\hline \multirow{2}{*}{$\begin{array}{l}\text { Reduced offtake for recovery } \\
\text { to } 0.5 \mathrm{~K} \\
\text { Species }\end{array}$} & \multicolumn{3}{|c|}{ Number of individuals } & \multicolumn{3}{|c|}{ Biomass for consumption (kg) } & \multicolumn{3}{|c|}{ Value to hunters (US\$) selling $50 \%$ of biomass } \\
\hline & $(H)-10 \%$ & $(H)-25 \%$ & $(H)-50 \%$ & $(H)-10 \%$ & $(H)-25 \%$ & $(H)-50 \%$ & $(H)-10 \%$ & $(H)-25 \%$ & $(H)-50 \%$ \\
\hline Great white-nosed monkey & $-4,296$ & $-4,235$ & $-4,289$ & $-16,326$ & $-16,093$ & $-16,297$ & $-\$ 4,490$ & $-\$ 4,426$ & $-\$ 4,482$ \\
\hline Crested mona monkey & $-3,247$ & $-3,201$ & $-3,240$ & $-11,690$ & $-11,522$ & $-11,664$ & $-\$ 3,215$ & $-\$ 3,169$ & $-\$ 3,207$ \\
\hline Gray-cheeked mangabey & $-3,207$ & $-2,895$ & $-1,609$ & $-24,693$ & $-22,295$ & $-12,389$ & $-\$ 6,790$ & $-\$ 6,131$ & $-\$ 3,407$ \\
\hline Medium- size duikers & $-4,095$ & $-3,857$ & $-3,542$ & $-65,516$ & $-61,710$ & $-56,669$ & $-\$ 18,017$ & $-\$ 16,970$ & $-\$ 15,584$ \\
\hline Blue duiker & -495 & -626 & 0 & $-2,326$ & $-2,942$ & 0 & $-\$ 640$ & $-\$ 809$ & $\$ 0$ \\
\hline Total & $-15,340$ & $-14,814$ & $-12,679$ & $-120,551$ & $-114,562$ & $-97,019$ & $-\$ 33,151$ & $-\$ 31,504$ & $-\$ 26,680$ \\
\hline
\end{tabular}

timeframes and unsustainable hunting rates, NPV was higher for the MSY scenario.

Though sustainable hunting at current $\left(t_{0}\right)$ population levels generates less biomass available for consumption than hunting at MSY, it would produce enough wild meat for a village population of 0.75 people $/ \mathrm{km}^{2}$ which is close to the global estimate (Robinson and Bennett, 2000a; Peres and Nascimento, 2006) of the human carrying capacity of tropical forests in terms of protein supply (i.e., 1 person $/ \mathrm{km}^{2}$ ).

If the whole area is hunted at MSY (i.e., when all hunted populations are at $0.5 \mathrm{~K}$ ), the three primate and four ungulate species could provide a sustainable supply of animal source foods over a 25-year period to an average of: a) 6,185 people in villages, covering $100 \%$ of daily protein requirements; or b) 13,402 people in provincial towns, meeting $46 \%$ of daily protein requirements; or c) 80,411 people in large cities, meeting $8 \%$ of daily protein requirements.

In contrast, when wildlife are being hunted unsustainably (business-as-usual), over 25 years the $10 \%$ depletion scenario supplied wild meat on average to only: (a) 3,755 people in villages; or (b) 8,137 people in towns, or (c) 48,820 people in cities, and the $50 \%$ depletion scenario supplied wild meat on average to: (a) 1,271 people in villages; or (b) 2,754 people in towns; or (c) 16,525 people in cities.

Unsustainable hunting (i.e., the 10, 25, and 50\% business-asusual scenario) only increased the supply of wild meat to village, town and city dwellers for the first 1 or 2 years with supply plunging to $<50 \%$ of the MSY scenario by years 6,10 and 19 in the 50,25 , and $10 \%$ unsustainable hunting scenarios, respectively.

\section{DISCUSSION}

In 1998, 40\% of Central African forest was within $10 \mathrm{~km}$ of a road (Abernethy et al., 2013). By 2017 that had increased to $53 \%$ (Koerner et al., 2017). Of the 177 species that are hunted in Central Africa (Taylor et al., 2015) for food, 97 are being hunted at unsustainable levels according to the IUCN Red List. In this paper, we showed that populations of commonly hunted species ( 3 primates and 4 ungulates) are likely being hunted at unsustainable levels (i.e., population abundance has fallen to an average of $0.3 \mathrm{~K}$ ) in a zone within $6 \mathrm{~km}$ of settlements, near Makokou in Gabon. Larger-bodied red duikers appear to be unsustainably hunted $(0.36 \mathrm{~K})$ up to $15 \mathrm{~km}$ away from settlements.

Establishing and enforcing rules to render hunting sustainable at current wildlife population levels across all zones would: (a) require hunters to substantially reduce their offtake for the initial years when unsustainable hunting generates higher offtake (Figure 2); and (b) generate approximately 20\% less biomass than managing wildlife populations at $0.5 \mathrm{~K}$ (scenario 2). Similarly, allowing populations to reach $0.5 \mathrm{~K}$ so that they could be hunted at MSY would require hunters to reduce offtake by as much as $282,166 \mathrm{~kg}$ over 2 to 3 years or until wildlife populations recovered to $0.5 \mathrm{~K}$. Persuading all hunters to reduce their offtake even for a few years is unlikely unless they are compensated for lost food and income. Legalizing hunting, only for hunters from villages with legitimate historical claims to nearby forest, may also not solve the problem if: (a) the majority of current hunters have legitimate claims to hunt; and, (b) traditional hunting zones do not extend beyond $15 \mathrm{~km}$ from villages, and thus are not under the jurisdiction of legitimate village hunters.

The government of Gabon has on more than one occasion voiced an interest in legalizing the trade in wildlife as food and using the tax revenue to finance wildlife conservation both within and outside of national parks and reserves. Results from this study show that for depleted populations to recover offtake would have to decrease substantially at least for a few years. As a result, tax revenues from a legalized trade would see a comparable decline during the recovery years, making it unlikely that taxes would even cover the costs of tax collection, let alone increase investment in wildlife law enforcement (Wilkie et al., 2006).

A shift from unsustainable to MSY hunting does initially impose costs on hunters. But the alternative business-as-usual scenario causes offtake to decline rapidly so that within 10 to 18 years, for the 50 and $25 \%$ unsustainable hunting scenarios, wildlife populations have been effectively wiped out (Figure 2).

The Koerner et al. (2017) data as interpreted in this paper show that wildlife populations in $32 \%$ of the study area (near zone $<6 \mathrm{~km}$ ) have already been depleted to $0.3 \mathrm{~K}$, and in $37 \%$ of the area (intermediate zone $6-15 \mathrm{~km}$ ) wildlife have been depleted to $0.56 \mathrm{~K}$. The remaining $31 \%$ (>15 $\mathrm{km}$ from villages), we assume, based on the reported paucity of human sign, to be only rarely hunted and thus wildlife populations might be near carrying capacity (i.e., 0.9 to $1.0 \mathrm{~K}$ ). Taken together, this means that 
wildlife populations within $68 \%$ (i.e., $>6 \mathrm{~km}$ from settlements) of the study area near Makokou are still in relatively robust health (i.e., they are near or above $0.5 \mathrm{~K}$ ). This is maybe not surprising as Gabon has a small human population (1.7 million-CIA World Factbook) for its geographic area. Moreover, $89 \%$ of Gabonese live in urban areas and $88 \%$ of the country is still covered in forest.

If the entire forest was depleted to the same level as the near zone (i.e., $0.3 \mathrm{~K}$ ), the forest might be emptied of wildlife in 5 to 10 years under current, unsustainable, hunting levels. Setting the initial abundance of all 7 species at $0.1 \mathrm{~K}$, leads to their extirpation within 3-4 years. In many areas of central Africa, the forest is already almost empty.

Even under the most optimistic scenario, where the near, intermediate and far zones are all hunted at MSY, the forest will only feed a small number of people. This means that legalization of hunting is not a solution for the poor rural families who depend on wildlife as their primary source of dietary protein. Even if hunting was legalized everywhere within $50 \mathrm{~km}$ from settlements $\left(5,807 \mathrm{~km}^{2}\right.$ - an area almost two times the size of either the state of Rhode Island or the country of Luxembourg) the maximum possible sustainable offtake would feed 6,185 people. This number drops to 4,235 if hunting is limited to within $15 \mathrm{~km}$ of settlements, and to 1,930 if hunting is restricted to $6 \mathrm{~km}$ of settlements. With human population growth in Gabon estimated at $1.92 \%$ in 2017 (CIA World Factbook), in 20 years the population will have increased by more than $50 \%$, with much of that growth being in urban areas. That said, in the future, all other things held constant, an even smaller percentage of the Gabonese village population can expect to get their protein supply solely from wildlife.

The situation in towns and cities is more complicated given that wild meat is a rival good, and the meat eaten in villages is no longer available to be consumed in towns and cities. Hunters can either use wild meat to feed their extended families or barter or sell some or all of it to purchase necessities or luxury items. If, implausibly, all animals from all zones hunted at MSY were traded to the nearest town and none were consumed in the hunters' villages, then $98 \%$ of the town of Makokou could get a minority (46\%) of their daily protein requirements from wildlife. This is not only unrealistic, but the residents of Makokou would still need to find $54 \%$ of their daily protein requirements from other animal source foods.

The production of wildlife is limited by the availability of high-quality habitat. In Gabon and across central Africa, wildlife habitat is shrinking, not expanding, as forest lands are converted to farms, plantations, mines, roads and settlements (Austin et al., 2017; Kleinschroth et al., 2019). So, supply is either optimistically likely to remain static at MSY (assuming we can manage hunting sustainably) or, more realistically, will shrink as non-hunting factors like habitat destruction begin to drive down wildlife populations.

Rarely do Gabonese hunters trade more than $50 \%$ of the animals they hunt (Coad, 2007; Table 5.1), but this could change if consumers were willing to pay higher prices. If supply shrinks and/or demand increases, we might expect the price to rise, because there is evidence that demand for wild meat in Gabon is relatively price inelastic (Wilkie et al., 2005; Foerster et al., 2012) when substitutes are more expensive or unavailable. If price rises, then hunters may be motivated to sell a greater portion of the animals they capture. With less wild meat, levels of protein and micro-nutrient deficiency and "failure to thrive" amongst children will increase in wild meat-dependent villages (Golden et al., 2011).

As the human population of Gabon continues to grow, and as successful poverty alleviation efforts increase household income, we expect demand for animal-source foods to increase substantially (Wilkie et al., 2016) coupled with static or declining wild meat availability. To avoid this looming protein deficit and to prevent protein-hungry people from eating wild animals to extinction, conservation organizations must convince development organizations and donors to invest in increasing the supply of sustainably produced animal-source foods. Additionally, these investments should focus on feeding growing provincial towns close to still relatively abundant wildlife populations, and large metropolitan cities where per capita demand for wild meat is small but the aggregate demand of millions of consumers is huge.

Loss of wildlife from unsustainable hunting and fishing will have irrevocable, long-term impacts on forest species composition, distribution, productivity, and carbon content (Poulsen et al., 2013). But this conservation crisis cannot solely be solved with the classical conservation solution (i.e., establishing and managing wildlife populations within state protected areas and community reserves). Rather, to avoid this looming protein deficit these provincial towns and metropolitan cities must be able to develop profitable and sustainable enterprise that can supply animal-source foods in sufficient quantity to meet demand.

Thankfully these towns and cities are large enough to support profitable private-sector livestock, farmed fish, marketing, butchering, and veterinary-care enterprises. A focus on family-scale, back-yard production of new, more disease-resistant and productive breeds of poultry and other small livestock (guinea pigs and rabbits), makes sense for several reasons. Back yard production, minimizes capital costs, helps empower women as they are often the small livestock owners and producers, increases opportunities for unemployed and under-employed youth, avoids the need for cold chains (i.e., refrigerated supply chains), and is scalable as additional back-yard producers adopt observably successful innovations. Avoiding this looming protein deficit will not only help conserve wildlife hunted for food, it will increase household food and income security, reduce unemployment, and might also reduce motivation for youth and whole families to leave relatives and their homelands to seek a better life elsewhere.

This paper shows that current levels of hunting of wildlife for food and income risks fully depleting wildlife populations within $6 \mathrm{~km}$ of settlements. Gabon's growing human population 
will increase wild meat demand. Coupled with habitat loss and a reduction in wildlife production, our model suggests that current levels of hunting risk depleting wildlife across the landscape. To transition from unsustainable to sustainable hunting will require substantial reduction in hunting levels to allow depleted wildlife populations to recover. During this recovery period the supply of wildlife for food and income will be significantly lower than it is currently. Hunters are unlikely to willingly reduce the benefits they gain from hunting at current levels, even if they are not sustainable over the next 20 years. The government of Gabon and its conservation partners will need to find ways to offset the short-term losses of food and income until wildlife populations recover, otherwise hunters will have little interest in complying with sustainable hunting regulations and may take actions to undermine them.

\section{AUTHOR CONTRIBUTIONS}

DW and MW contributed the initial concept. JP provided the wildlife abundance data from Gabon. DW developed the simulations. DW, MW, and JP contributed to the writing of the paper.

\section{REFERENCES}

Abernethy, K. A., Coad, L., Taylor, G., Lee, M. E., and Maisels, F. (2013). Extent and ecological consequences of hunting in Central African rainforests in the twenty-first century. Philos. Trans. R. Soc. Lond. B Biol. Sci. 368:20120303. doi: 10.1098/rstb.2012.0303

Alexandratos, N., and Bruinsma, J. (2012). "World agriculture towards 2030/2050: the 2012 revision," in ESA Working Paper No. 12-03 (Rome: FAO).

Austin, K. G., Lee, M. E., Clark, C., Forester, B. R., Urban, D. L., White, L., et al. (2017). An assessment of high carbon stock and high conservation value approaches to sustainable oil palm cultivation in Gabon. Environ. Res. Lett. 12:014005. doi: 10.1088/1748-9326/aa5437

Beirne, C., Meier, A. C., Mbele, A. E., Menie Menie, G., Froese, G., Okouyi, J., et al. (2019). Participatory monitoring reveals village-centered gradients of mammalian defaunation in central Africa. Biol. Conserv. 233, 228-238. doi: 10.1016/j.biocon.2019.02.035

Bennett, E. L., Blencowe, E., Brandon, K., Brown, D., Burn, R. W., Cowlishaw, G. U. Y., et al. (2007). Hunting for consensus: reconciling bushmeat harvest, conservation, and development policy in west and central Africa. Conserv. Biol. 21, 884-887. doi: 10.1111/j.1523-1739.2006.00595.x

Bodirsky, B. L., Rolinski, S., Biewald, A., Weindl, I., Popp, A., and Lotze-Campen, H. (2015). Global food demand scenarios for the 21st century. PLoS ONE 10:e0139201. doi: 10.1371/journal.pone.0139201

Box, G. E. (1979). All models are wrong, but some are useful. Robust. Stat. 202:549.

Charnov, E. L. (1976). Optimal foraging: attack strategy of a Mantid. Am. Natur. 110, 141-151. doi: 10.1086/283054

Coad, L., Schleicher, J., Milner-Gulland, E. J., Marthews, T. R., Starkey, M., Manica, A., et al. (2013). Social and ecological change over a decade in a village hunting system, central Gabon. Conserv. Biol. 27, 270-280. doi: 10.1111/cobi. 12012

Coad, L. M. (2007). Bushmeat hunting in Gabon: socio-economics and hunter behavior ( $\mathrm{PhD}$ thesis). University of Cambridge, Cambridge, United Kingdom.

Cole, L. C. (1954). The population consequences of life history phenomena. Quart. Rev. Biol. 29, 103-137. doi: 10.1086/400074

Desa, U. (2015). World Population Prospects: The 2015 Revision, Key Findings and Advance Tables. Working Paper No. ESA/P/WP.241.

\section{FUNDING}

The European Commission Directorate-General for International Cooperation and Development (DG DEVCO) and the United Nations Food and Agricultural Organization for financial support to DW and MW. Duke University provided funds to JP for field data collection.

\section{ACKNOWLEDGMENTS}

The authors would like to thank the Government of Gabon, in particular the Center National de la Recherche Scientifique et Technologique (CENAREST) and the Agence Nationale des Parcs Nationaux (ANPN) for permission to collect field data, and would like to thank Dr. Timothy O'Brien and Dr. Samantha Strindberg for their comments on the concept and a technical review of the simulation. We would also like to thank the European Commission Directorate-General for International Cooperation and Development (DG DEVCO) and the United Nations Food and Agricultural Organization for financial support to DW and MW. Field data collection for this paper was supported by funds provided to JP from Duke University.

Fa, J. E., Juste, J., Perez del Val, J., and Castroviejo, J. (1995). Impact of market hunting on mammal species in Equatorial Guinea. Conserv. Biol. 9, 1107-1115. doi: 10.1046/j.1523-1739.1995.951107.x

Foerster, S., Wilkie, D., Morelli, G., Demmer, J., Starkey, M., Telfer, P., et al. (2012). Determinants of bushmeat consumption among rural households in Gabon, Central Africa. Conserv. Biol. 26, 335-344. doi: 10.1111/j.1523-1739.2011.01802.x

Gally, M., and Jeanmart, P. (1996). Etude de la chasse villageoise en foret dense humide d'Afrique centrale Faculté Universitaire des Sciences Agronomiques de Gembloux.

Golden, C. D., Fernald, L. C. H., Brashares, J. S., Rasolofoniaina, B. J. R., and Kremen, C. (2011). Benefits of wildlife consumption to child nutrition in a biodiversity hotspot. Proc. Natl. Acad. Sci. U.S.A. 108, 19653-19656. doi: $10.1073 /$ pnas. 1112586108

Kingdon, J., Happold, D., Butynski, T., Hoffmann, M., Happold, M., and Kalina, J. (2013). Mammals of Africa. London: Bloomsbury Natural History.

Kleinschroth, F., Laporte, N., Laurance, W. F., Goetz, S. J., and Ghazoul, J. (2019). Road expansion and persistence in forests of the Congo Basin. Nat. Sustain. 2, 628-634. doi: 10.1038/s41893-019-0310-6

Koerner, S. E., Poulsen, J. R., Blanchard, E. J., Okouyi, J., and Clark, C. J. (2017) Vertebrate community composition and diversity declines along a defaunation gradient radiating from rural villages in Gabon. J. Appl. Ecol. 54, 805-814. doi: 10.1111/1365-2664.12798

Peres, C., and Nascimento, H. (2006). Impact of game hunting by the Kayapo of south-eastern Amazonia: implications for wildlife conservation in tropical forest indigenous reserves. Biodivers. Conserv. 15, 2627-2653. doi: 10.1007/s10531-005-5406-9

Poulsen, J. R., Clark, C. J., and Palmer, T. M. (2013). Ecological erosion of an Afrotropical forest and potential consequences for tree recruitment and forest biomass. Biol. Conserv. 163, 122-130. doi: 10.1016/j.biocon.2013.03.021

Reynolds, J. D., Mace, G. M., Redford, K. H., and Robinson, J. G. (2001). Conservation of Exploited Species. Cambridge: Cambridge University Press; The Wildlife Conservation Society; The Zoological Society of London.

Ripple, W. J., Abernethy, K., Betts, M. G., Chapron, G., Dirzo, R., Galetti, M., et al. (2016). Bushmeat hunting and extinction risk to the world's mammals. R. Soc. Open Sci. 3:160498. doi: 10.1098/rsos.160498 
Robinson, J. G., and Bennett, E. L. (2000a). "Carrying capacity limits to sustainable hunting in tropical forests," in Hunting for Sustainability in Tropical Forests, eds. J. G. Robinson and E. L. Bennett (New York, NY: Columbia University Press), 13-30.

Robinson, J. G., and Bennett, E. L. (2000b). Hunting for Sustainability in Tropical Forests. New York, NY: Columbia University Press.

Starkey, M. (2004). Commerce and subsistence: the hunting, sale and consumption of bushmeat in Gabon (Ph.D. Dissertation). Cambridge University, Cambridge, United Kingdom.

Taylor, G., Scharlemann, J. P. W., Rowcliffe, M., Kumpel, N., Harfoot, M. B. J., Fa, J. E., et al. (2015). Synthesising bushmeat research effort in West and Central Africa: a new regional database. Biol. Conserv. 181, 199-205. doi: 10.1016/j.biocon.2014.11.001

Trolliet, F., Bauman, D., Forget, P.-M., Doucet, J.-L., Gillet, J.-F., and Hambuckers, A. (2019). How complementary are large frugivores for tree seedling recruitment? A case study in the Congo Basin. J. Trop. Ecol. 35, 223-236. doi: 10.1017/S026646741900018X

Wilkie, D. S., Bennett, E. L., Peres, C. A., and Cunningham, A. A. (2011). The empty forest revisited. Ann. N. Y. Acad. Sci. 1223, 120-128. doi: 10.1111/j.1749-6632.2010.05908.x

Wilkie, D. S., Bennett, E. L., Starkey, M., Abernethy, K., Fotso, R. C., Maisels, F., et al. (2006). If trade in bushmeat is legalized can the laws be enforced and wildlife survive in Central Africa: evidence from Gabon. J. Int. Wildlife Law Policy 9, 335-349. doi: 10.1080/138802906010 39287

Wilkie, D. S., Starkey, M., Abernethy, K., Effa Nsame, E., Telfer, P., and Godoy, R. (2005). Role of prices and wealth in consumer demand for bushmeat in Gabon, Central Africa. Conserv. Biol. 19, 1-7. doi: 10.1111/j.1523-1739.2005.0 0372.x

Wilkie, D. S., Wieland, M., Boulet, H., Le Bel, S., Vliet, N., Cornelis, D., et al. (2016). Eating and conserving bushmeat in Africa. Afr. J. Ecol. 54, 402-414. doi: 10.1111/aje.12392

Conflict of Interest: The authors declare that the research was conducted in the absence of any commercial or financial relationships that could be construed as a potential conflict of interest.

Copyright (c) 2019 Wilkie, Wieland and Poulsen. This is an open-access article distributed under the terms of the Creative Commons Attribution License (CC BY). The use, distribution or reproduction in other forums is permitted, provided the original author(s) and the copyright owner(s) are credited and that the original publication in this journal is cited, in accordance with accepted academic practice. No use, distribution or reproduction is permitted which does not comply with these terms. 